\title{
Developing Islamic English Instructional Materials Based on School-Based Curriculum
}

\author{
Zaitun Qamariah \\ IAIN Palangka Raya \\ zaitunqamariah@yahoo.com
}

\begin{abstract}
This study was a research and development (R\&D) which is basically aimed at developing English instructional materials based on School-based Curriculum for the first-year students of MAN Model Palangka Raya. This study involved: need analysis, reference study, material development, expert validation, try out (empirical validation), and revision. The data were gathered through observation, questionnaires, interview, and validation technique. The result of the need analysis shows that the students are in need of English instructional materials relevant to their major content needs and school characteristics. However, the existing English instructional materials used by the teachers and the first-grade students of MAN Model Palangka Raya as a senior high school with Islamic feature still served from available published course books which are too general and still do not reflect the need of the students and particular characteristics of the school. English instructional materials developed in this study is intended to develop English instructional materials which could provide a set of instructional materials to accomodate the Islamic characteristics and the needs of the first-year students of MAN Model Palangka Raya. For the purpose, the materials were adopted and adapted from some Islamic textbooks and Islamic reading websites.
\end{abstract}

Keywords: research and development, Islamic English instructional material, schoolbased curriculum

There are many instructional materials available on the market, covering many different aspects of language learning and language use. It varies from comprehensive general courses, supported by taped and visual material, to specialized books which concentrate on one aspect of English or one specific skill. Other books deal with specific kind of English, yet other offer exercises for certain stages in the learning process. Thus, it is rare to meet a teacher who does not become a greater or lesser extent draw on published teaching material. Some may even use one coursebook only and taking the students through it from beginning to the end. Teacher used to expect that coursebook from trustworthy publishers will be a good instructional materials provider.

One of the main educational interests is development of instructional material. According to Tomlinson in Carter \& Nunan (2001:66), research on material development is a recent phenomenon. In education, instructional material development is the area that tends to attract the most exaggerated claims of 
success. The key question is always whether this is reflected in classroom practices and in improved learning. Therefore, it is important for teachers to know how to choose the best material for instruction, how to make supplementary materials for the class, and how to adapt materials.

However, many course books, as stated by Cunningsworth (1984:2), are too general to be used in teaching, not only in that they attempt to all aspect of English but also in that they are designed to satisfy general wide market. Such materials do not have one particular group of learners in mind and therefore usually take an English-speaking country as a setting along with corresponding sets of cultural values.

Although this is largely the teachers' job, but course material can help by using subject material that is intellectually stimulating and to which the students can relate personally. It is also important that the material should be usable with whole classes of learners, with small groups, and with individuals. This is because the students need to be catered for both as individuals and as members of a group. Within the space of one lesson, a student may act alternately as an individual and a group member. Faced with mass of teaching material, teacher should ideally have skill or knowledge to make choice or selection.

Up to the present, teaching learning process at MAN Model Palangka Raya used a new curriculum called Schoolbased Curriculum which states that the curriculum developed by the school should be in consideration of the school needs and characteristics. As the consequence, the school should develop their own syllabus and instructional materials which can accommodate their needs. The need and the characteristic of MAN Model Palangka Raya are to prepare the students with knowledge and religiosity, in this case about Islamic value. English materials for the students of MAN Model Palangka Raya are served from available published course book. However, the existing materials for English teaching do not suit the need of the student. Thus, the teaching and learning process of English language is still facing various problems as shown by the students' unsatisfactory learning outcomes that can be seen in their summative test achievement.

This failure could be due to quite a few factors. One of them is lack of suitable English instructional material for students. The next factor is that teacher centered approaches are still in practice and no need analysis of students' need is implemented before making decision on what kind of teaching material used in teaching learning process. Those problems actually can be overcome by developing a suitable English teaching material which can be promoted in the teaching of English when it is proved useful.

Instructional material is anything which can be used to facilitate the learning. In the case of language instructional materials, as stated by Tomlinson in Nunan, et al. (2001:66), they can be linguistic, visual, auditory or kinesthetic, and they can be presented in print, through live performance or display, or on cassette, CD-ROM, DVD, or the internet. They can be instructional in that they inform learners about the language, experiential in that they provide exposure to the language in use, elicitative 
in that they stimulate English language use, or can be exploratory in that they seek discoveries about language use.

English Instructional Materials development in this study is both a field of study and a practical activity. As a field it studies the principles and produce of the design, implementation and evaluation of language Instructional materials. As an activity, it involves the production, evaluation, and adaptation of language Instructional materials classroom.

There are some reasons why teachers need to develop their own Instructional material. Among them are; availability of materials which is appropriate-tocurriculum, characteristics of the students, and the needs to solve the problem in teaching learning. The guidance of teaching material development is as suggested by Badan Standar Nasional Pendidikan (2006:13), it puts the potencies of the students, characteristics of subject and geographic, and the advantages for the students as the point of consideration in developing teaching material.

In developing instructional materials, the key to effective one is that they must be effective, efficient, and appealing to students. They should be written in the language of students and aimed at students. As such, they should be written at the reading level of students. They should contain text, visuals, and other elements that will assist the diverse group of learners succeed. They should include analogies, scenarios, and examples that are motivating and interesting. Besides, learning materials should use techniques that stimulate creative and critical thinking. They may contain reflective questions or ideas for organizing thinking.
The objectives of developing instructional material are (1) to provide teaching material which is appropriate to the needs of curriculum by considering the needs of students, that is a teaching material appropriate to the characteristics, setting, or students' social environment, (2) to assist the students in completing alternative reference, and (3) to help the teacher in teaching learning process (Departemen Pendidikan Nasional, 2008:9).

Based on a study of English textbooks published in Japan in 1985, the textbooks were reviewed and problems were found with both the language and content of many of the textbooks (Kitao, et al., 1997). The problems are as follows:

1. Language. English textbooks should have correct, natural, recent, and English standard. Since students' vocabulary is limited, the vocabulary in textbooks should be controlled or the textbooks should provide information to help students understand vocabulary that they may not be familiar with. For lower-level students, grammar should also be controlled. Many textbooks use narratives and essays. It would be useful to have a variety of literary forms (for example, newspaper articles, poetry, or letters), so that students can learn to deal with different forms. Information on Culture. The cultural information included in English textbooks should be correct and recent. It should not be biased and should reflect background cultures of English. It should include visual aids etc., to help students understand cultural information.

2. Learners' Viewpoints. Content English textbooks should be useful, meaningful and interesting for students. While no 
single subject will be of interest to all students, materials should be chosen based, in part, on what students, in general, are likely to find interesting and motivating.

3. Difficulty. As a general rule, teaching materials should be slightly higher in their level of difficulty than the students' current level of English proficiency. (Exceptions are usually made for extensive reading and extensive listening materials, which should be easy enough for students to process without much difficulty.) Materials at a slightly higher level of difficulty than the students' current level of English proficiency allow them to learn new grammatical structures and vocabulary.

Despite the various approaches, there are certain general principles, based on good language teaching practice, which will help in evaluating Instructional materials which have been developed. Cunningsworth (1995:5) suggests four principles in evaluating teaching materials as follows:

1. Relate the teaching materials to the aims and objectives. It is very important that the Instructional materials used should take the learner forward as directly as possible towards the objectives. The objectives should be decided first, in line with the overall aim of teaching program, and then the material should be sought which can be related to these objectives. The aims of teaching program should determine the course materials to be used and not vice versa.

2. Be aware of what language is for and select teaching materials which will have equip the students to use language effectively for their own purposes. The teaching must have its entire base a consideration of what our students need to learn, that is, what they will do with English on completing the course. This involves the teachers in looking beyond the confines of the classroom into the outside world, and focusing attention on the use that the individual learner will make of what they learned, in a situation which is not primarily a learning situation.

3. Keep the students' learning needs in mind. In order to learn effectively and efficiently, students should meet only small pieces of new language at one time, that it might be call learning units. These learning units should be related to each other in such a way that the learner can relate new language to what he already knows and can build up his knowledge of English by adding new learning units to his existing body of knowledge. But, learning needs are not limited solely to considerations of the language. Learners have intellectual and emotional needs too. Learning a language is difficult and demanding, and student needs to be encouraged and stimulated as they progress. This is largely the teacher's job, but teaching materials can help by using subject matter that stimulating and to which the students can relate personally. It is also important that materials should be usable with whole classes of learners, with small groups and individuals. This is because students need to be catered for both as individuals and as members of a group. Within the space of one lesson a student may act alternately as an individual and a group member, depending on several factors including the sort of exercise he is doing, the 
skills that are being practiced and his own learning strategies.

4. Consider the relationship between language, the learning process and the learner. All three are vital aspects of language teaching and it is essential that teaching materials should keep all three constantly in view and never become so pre-occupied with one the others are lost sight of. What is unknown about language learning processes leads to believe that there is no one best way of learning and learners adopt different learning strategies, often switching strategies from time to time. Learning activities, no matter how interesting and involving, will not be of much help to the learners of English unless they present and practice English in a systematic and comprehensive way so that the new language items can be assimilated by the learner. There is currently something of a tendency to use activities for their own sake, because they are enjoyable or because they work as activities, without due regard to their values as language learning exercises. Of course the thing students do in class should be interesting and enjoyable, but they should also be carefully examined in terms of their language teaching potential.

When all is done, validation is the final steps in the systematic design and development of an instructional program. Essef (1974:2) states that the first step in validation is, most naturally, selecting the students who will be trying out the materials. One thing essential to remember in this point is that there is not testing the students selected, but, testing the materials and program. In selecting the validators, then, it is important to select students who most closely resemble those who will be working through the final program.

In the development of School-based Curriculum, which vary based on National Education Standards (SNP) to ensure the achievement of national education goals, National Standards of Education Content Standard, Standard Process, Competency standards Passed, Education Workforce Standards, Standards for Infrastructure, Standards Management, Financing Standards, Assessment Standards. Two of the eight standards, which are national education and Competency Standards Content Standard passed, are the main references for the education unit in developing curriculum. Law of the Republic of Indonesia Number 20 Year 2003 (UU 20/2003) about the System of National Education and the Indonesian Government Regulation Number 19 Year 2005 (PP 19/2005) about the National Standards of Education has mandated curriculum unit level education of primary and secondary levels of education have been prepared by educational unit based on the content standards and pass the competency standards. School-based Curriculum is an operational curriculum developed and implemented by each educational unit which emphasize on developing the ability to do (competence) and tasks with specific performance standards so the results can be felt by students in the form of mastery of a set of specific competencies. This educational program standard device should be able to deliver students to have a competency of knowledge, and values used in various fields of life. 
In addition, the development principles of School-based Curriculum stated by Badan Standar Nasional Pendidikan (2006) are (1) centered on the potential, progress, needs and interests of learners and their environment, (2) diverse and integrated, (3) response to the development of science and art, (4) be relevant to the needs of life, (5) comprehensive and continuous, (6) long life education, and (7) balance between national interests and regional interests.

Based on the background above, it is very important to conduct research aimed at developing English instructional materials based on School-based Curriculum for the first-year students of MAN Model Palangka Raya.

\section{METHOD}

To meet the purpose of this study, education research and development $(\mathrm{R} \& \mathrm{D})$ is considered as the appropriate design to apply. The model of research and development suggested by Borg and Gall was adapted to accomplish the finished product; that is a model of English teaching material based on School-based Curriculum which is suitable for the first-year students of MAN Model Palangka Raya.

The experts have introduced a wide variety of models in developing materials using the $\mathrm{R} \& \mathrm{D}$ Approach. The models are principally the same in goal, but different in procedures, depending on such factors as educational system, condition of students and teachers, learning situation, etc. Yet, in line with the stages suggested by Borg (1983), Hutchinson \& Waters (1991), and Dick \& Carey (2001), only some stages are considered to be applicable in developing
English teaching material for the first-year students of MAN Model Palangka Raya. These stages involve the following procedures as shows in Figure 1.

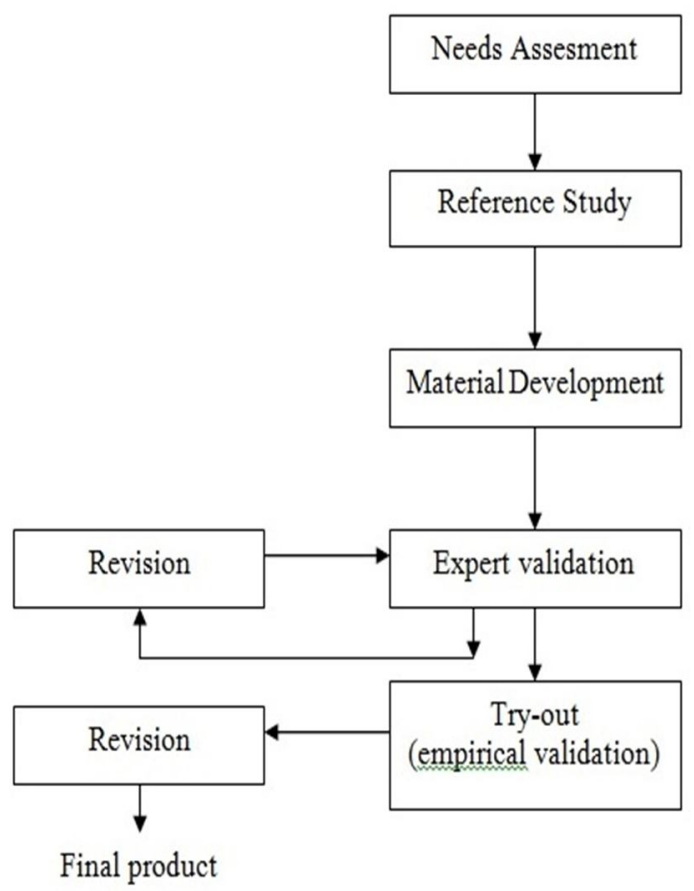

Figure 1 The Procedure of the Development

\section{FINDINGS AND DISCUSSIONS}

The Result of the Needs Assessment

The data of the needs assessment covered information of what the students need to learn. The data were collected by using questionnaire on students and English teachers. Based on these data, then, the first draft of the material was developed.

The Questionnaire about the School Demand towards English Instructional Materials in MAN Model Palangka Raya

The questionnaire was given to the English teachers who teach in the first grade of 2010/2011 school year. It was used to collect information about the applicability of the book in terms of level 
of difficulty, effectiveness and attractiveness, usefulness, the topics, the design, the skills, the exercises, the method of teaching, and teacher's book of the existing book to MAN Model Palangka Raya based on the teachers' perception. The data could be identified and analyzed as follows:

\section{The Objectives and Topics}

Based on the teachers' responses on the questionnaire, the current book actually has been in line with Schoolbased Curriculum. Considering the students' needs, towards teaching and learning, they agreed that each school should develop its own criteria for selecting the topics of instructional materials which related to two general requirements for selections: materials must (1) have a clear connection to established educational objectives and (2) address the needs of the students for whom they are intended.

In this term, English Instructional materials in MAN Model Palangka Raya should align with the general philosophy of the school, the curriculum goals and objectives of the English learning, and the learning outcomes of the particular course or grade level. For instance, some materials may be included because they reflect the school's philosophy of encouraging critical thinking in relation to controversial situations and points of view. Or materials may be included because they meet the curriculum objective of presenting accommodate voices from different eras or diverse cultures. Or they may be included to address specific learner outcomes.

In relation to the design of instructional material, based on the teachers' responses, all kind of colorful photos, pictures, graphs, charts, maps, and illustrations can invite the excitement of students in English learning. They were proved good for conveying concrete images and providing support material when teaching a concept, as a way of avoiding technical jargon, and for conveying visual and spatial concepts. Besides, they are also good for conveying ideas that have to be considered simultaneously.

Responding to these questions, the teachers answered that the developed material should integrate all those four skills. There are many situations in which more than one language skill is needed. For this reason, it is valuable to integrate the language skills. Integrating the skills will allow the students to build in more variety into the lesson because the range of activities will be wider. Instead of just having listening, the students can have speaking, reading and writing practice. This can raise their motivation to learn English. Moreover, the teachers stated that all skills are important. None of them can be ignored.

\section{The Questionnaire about the Students' Needs towards English Instructional Materials}

There were thirty students in the first year of MAN Model Palangka Raya involved in the questionnaire and try-out activities. Ten students were from above average achievers, ten students from average achievers, and ten students were from below average achievers who were chosen and considered adequate. The questionnaire was distributed to them, and all of them had answered all the questions in questionnaire and had 
returned them to the researcher, so that the needed information could be identified.

The questionnaire for the students was firstly tabulated. Every component was evaluated by using percentage, thus, it was converted into qualitative data such as $100 \%$ (all), $90-99 \%$ (mostly), $80-88 \%$ (a lot of), $50-79 \%$ (many), 30-49\% (some), 1 29 (less), and $0 \%$ (None). The format of questionnaire can be seen in appendix. The interpretation of the data gathered was described in the following discussion.

\section{Design of the Book}

To find out the indicators of the design of instructional material needed, the questions were focused on variety of illustrations or pictures which considered invite the excitement of the students on English learning. From the students responses on the questions can be concluded that all of the students $(100 \%)$ claimed that the design of instructional material is important and should be ideally interesting. On the second and third question, all of the students $(100 \%)$ prefer colorful pictures and many students $(53 \%)$ prefer colorful photographs to improve their motivation and understanding in English learning. None of the students $(0 \%)$ were interested in black and white pictured and photographs. This is shows that Picture still becomes an existing point in learning.

\section{Topics of Materials}

Concerning on the topics of instructional material at the question four, all of the students (100\%) thought that the topic should be interesting. Most of students $(90 \%)$ considered the topic is interesting when it is related to their background or prior knowledge. Many students $(60 \%)$ prefer the topics on new information they want to know, while most of them $(93 \%)$ prefer daily topics.

\section{Skills}

Regarding with the skills in English learning, some students (43\%) agreed to listening skill as the priority in English learning. $73 \%$ on reading skill, $50 \%$ on writing skill, and many students (76\%) stated that Speaking is the most important skill among others to be mastered in English learning.

\section{The Selection of the First Draft Materials}

Considering the data collected from the needs assessment, the first draft of the proposed English instructional material was developed. The draft, was mainly developed on the basis of School-Based Curriculum. It was divided into three (3) units with topics as a heading in each unit. The topic were chosen based on that were ordered according to the complexity, but they were presented under the topics the students usually encountered in daily lives.

The topics of the materials were taken from Islamic English handbook, and many others which are used in their major content subject courses, such as How to use hijab, or wudhu before prayers. With these materials there are about the current events in the real world as moslem, and the students may find it easier to relate to their own experience or knowledge and be able to appreciate the use of language in those materials. Authentic materials can provide valuable support to the comprehension of the major content subjects as they have to study. 
With the division of the items into those three (3) units and topics, it was possible to fulfill what the students mostly needed to learn. With four integrative skills as requirements, the materials were developed in such a way that the tasks in each unit or each topic usually encouraged the students. First of all, to listen or to read, then they had to relate this prior knowledge to the context of their real life situation. Therefore, the language components, such as grammar, which students also needed to learn, were not taught as separate parts of the language, but they were integrated in the practices of the four skills. Only in the end of each unit was the students' knowledge of grammatical structures reviewed by asking them to do some grammar exercises.

\section{Analysis of the Development of Instructional materials \\ Development of Instructional Materials}

The purposes of the development of instructional material for the first year students of MAN Model Palangka Raya are (1) to give the students reading materials that are intellectually stimulating based on their interest and needs but not beyond their lexical or grammatical understanding, (2) to provide activities that makes the comprehension of the instructional materials easier, and (3) to provide the students with the topics and tasks that enable them to develop more knowledge, skills, and competence in English.

Based on the above discussion, the lecturer and the major content subject teachers are act as a consultant to select, explain, clarify, and apply the instructional materials. They both worked together in developing materials. Based on the result of questionnaire and interviews, an instructional material for the first year students of MAN Model Palangka Raya was developed in this study. It is based on the adapted criteria from need analysis. It is also based on the objective, design, and selection of the materials as stated earlier.

\section{Validation of the Developed \\ Instructional Materials}

Validation of the instructional materials was done by giving the developed materials to the expert of material development to be commented and evaluated. After 3 sections of instructional materials had been developed, the first draft was consulted, and through times of consultation, the data in improving the first data could be collected.

To evaluate the draft, the researcher arranged a validation form to be filled by the expert and the one of the English teacher. In the validation form, the researcher did not limit the form with specific questions in order to get information needed as much as possible. The results showed the identification of some positive and negative points of the draft.

\section{The Strength of the Draft}

As the first point of validation identified by the expert and teacher, the cover design of the instructional materials was attractive and invites the excitement of the students. Besides, the use of the letter was quite clear, appropriate, consistent, and readable. The typing was clear, neat, and regular. 
The next second point of validation was related to the organization of material. According to the expert, the instructional material developed was organized attractively. They were organized in logically ordered task, and, related to the form of units and sections; they had been formed in appropriate way.

The third positive point identified by the expert dealt with the instructional objectives which were clear and also stated clearly. Connected to the next positive point, that was the topics, which were in line with the students' needs and interest. Besides, the topic had been relevant to the students' subject content, compiled of various kinds and quite up to date.

On grammar review points, the expert identified that the grammar review was relevant to the students' needs and appropriate to the given context. Dealt with tasks points, the tasks were appropriate to the given context, quite communicative, easier and can be done by the students, and then encourage involvement of the students individually and as a team. Besides, the tasks could also integrate knowledge of the students about the topics and the language they learnt. On instruction point, the expert identified that the instructions were clear, appropriate and can be understood by the students.

The next point dealt with coverage of materials which was relevant, appropriate, to the students' needs and interests, and also represent the aspect of language skills. Related to content of materials, the content had been clear, appropriate, logically ordered, relates directly to the objectives of the instruction, and can be understood by the students.
Another positive point on instructional material draft dealt with language aspect. Here the expert identified that the language used in the draft had become an appropriate model of the correct and meaningful grammatical structures.

\section{The Weaknesses of the Draft}

The first negative point of the draft identified by the expert was connected to the physical appearance of letter spacing. Some spacing was given inappropriately and could possibly distract the students' concentration.

The second negative points dealt with grammar review. As identified by the expert, some of grammar review was not representative of the underlying grammar rules and thus, should be added.

The third negative point was laid on examples. Some examples were considered not consistent, unclear, inappropriate, and not defining concepts clearly and adequately, and they should be revised.

The last negative point dealt with language identified by the expert was about the language. Some language aspects on the draft were considered did not match the students' level, too difficult, and could hardly understood by the students.

In addition to the previous points, the experts and the English teacher also gave some notes and suggestion on the revision of the first draft. As suggested by the experts and the teachers, the example texts on the draft were too long. Thus, it is better to make adaptation and eliminating some of unimportant points of the texts so that the students will not be bored and exhausted every time they should face the 
example of the text. Thus, it should be revised. Connected with pictures or visual help, to maintain the students' interest, the pictures should stay in line with the topics. Then all pointers of proper nouns, connectors and others should be signed or underlined clearly. Comments of the experts were also inferred that sub unit should not be given in one session only. One session should cover part of activities in sub unit.

\section{Try Out of the Developed Instructional Materials}

After being selected, developed, and validated, the drafts of instructional materials were tried out. There were thirty students which taken from the group of above average, average, and below average achievers respectively to do the try out. The try out was given almost in the end of the first semester, so both students and teacher had limited time. Therefore, there were only two units of the revised draft of the instructional materials were tried out. Each unit was tried-out in two meetings, so, there were totally four (4) try out meetings needed.

The researcher, as the key instrument observed the process of try out and noted down every relevant thing happened during and along the process. Then by the end of try out, a questionnaire were distributed to gain supporting and additional data connected to instructional material applicability and revision.

\section{Analysis of the Try Out Instructional Materials}

During the try-out observation, there was an impression that the students were very familiar with the topics discussed in instructional materials. At the first meeting, in "have a start" activity, when they see the picture, most of them seemed excited and directly started the discussion among them about what the picture actually talk about. They seemed curious of what would they learn through the picture. After the teacher made association between the picture and their topic, it seemed that they became more active in discussion along the first meeting.

At the second, third and last meeting, the situation seemed to be more conductive than before. The students seemed to enjoy the materials and the tasks which had been combined in various colorful pictures, familiar topics, and activities. They show their effort to understand the materials by discussing it with their friends. They seemed enjoy and showed great interest when their classmates presented assignment or performed in front of the class. The instructional material which had been composed provided students with the topics they can really find in the real life situation seemed to refresh the students intention in English learning.

\section{The Result of Interview}

There were two kinds of interview dome by the end of the tryout. The first interview was given to the students who took part in the try out, and the second interview to the colleague teachers whose classes had been used for the try out. Through these interviews, which were held using the interview guidelines, the following additional data about the applicability of the material could be collected and described as the following.

Concerning the selection of the topic materials, most of the students and the teacher had the same opinion. They said 
that the topics were interesting since it was familiar and bring about the real life situation and relevant to their content subject and their needs. They also stated that they found some advantages in learning English by using religious content materials.

For the task found in the materials, the students confirmed that the task given was quite clear, encouraging, and communicative, and could be done. They also stated that the tasks were integrating their knowledge and language skills. Their opinions were supported by the teacher, in which they stated that the tasks were encouraging since it was in the scope of the students' ability to do them. Besides, the tasks were also related to what students were very familiar and have known before, thus, it make them easier to be understood and done.

In terms of language usage in instructional material, the students and teacher had the same opinion that the language used was appropriate with the educational level of students of MAN Model Palangka Raya. The clarity of the language considered helpful for the students and the teacher in teaching learning process.

\section{Revision of the Try Out Materials}

Revision was done based on the result of validation and try out. Based on the data so far, there were still some weaknesses of the materials that should be revised. One of them is dealt with time allocation. As suggested by the expert, the time allocated for each unit should be revised. Formerly it was expected that each unit is completed within each meeting. However, after being tried out, it is found that one meeting could not cover the sub unit. So, that it is determined to use two or three meetings for each unit.

With such revision, the instructional material is expected to become more appropriate and applicable for the first year students of MAN Model Palangka Raya. It was expected that the revised material could help the students in their effort to master English.

\section{Final Version of the Instructional \\ Materials}

After going through several revisions and adjustments, the development of the instructional material in this study resulted in the final version which is in the form of first semester English instructional materials for the first-year students of MAN Model Palangka Raya. The materials were developed on the basis of standard of competencies set in Schoolbased Curriculum. Besides, the materials were developed on the basis of the data collected from the need analysis which then revised based on the data given by expert, colleague teacher, and the students in the validation process and try out session. Finally the book are expected to give contribution in creating meaningful English learning since it was developed based on the students' needs, interest, and subject content.

\section{CONCLUSION}

From the above discussions it can be concluded that the English instructional materials developed in this study can be an alternative of English instructional materials to solve the English teaching and learning problem in MAN Model Palangka Raya. The materials were developed based on the needs, interest, and motivation of the first-year students 
of MAN Model Palangka Raya, so that it is considered to be appropriate and applicable for them. The materials were developed in accordance with the principles of School-based Curriculum, consist of some tasks for the students to do and guidance to the teacher in using the material in the teaching learning process, and in line with the context of the student's life situation, especially the situation in their major institution. Besides, the topics in the material are exploited into several tasks that enable students to develop their listening, speaking, reading, and writing skills of English as well as their skill in English grammatical structure which expected to lead them to the mastery of language according to their level.

There are several suggestions provided related to this study. First, English Instructional materials should be developed by paying attention on the result of the assessment of the students' needs, combined with the institutional goals, and relevant to the curriculum of the study program. It is necessary for the teachers to be creative in implementing the developed material in the teaching and learning process. They should be able to facilitate the students with the atmosphere that encourage the students to be active in their learning, especially by bringing the simulated objects to the classroom or by using the real objects outside the classroom. For further development of materials, it is also advisable to do it on the basis of the students' major such as Natural Science, Social Science, and Language so that the terms and activities presented in the materials could be more specific.

\section{REFERENCES}

Badan Standar Nasional Pendidikan. (2006). Panduan penyusunan kurikulum tingkat satuan pendidikan jenjang pendidikan dasar dan menengah. Jakarta: Depdiknas.

Cunningsworth, A. (1984). Evaluating and selecting EFL teaching materials. London: Heinemann Educational Books.

Departemen Pendidikan Nasional. (2008). Panduan pengembangan bahan ajar sekolah menegah atas. Jakarta: Depdiknas.

Dick, W. \& Carey, L. (2001). The systematic design of instruction. London: Scott, Foresman and Company.

Direktorat Sekolah Menengah Atas. (2006). Pedoman memilih dan menyusun bahan ajar. Jakarta: Depdiknas.

Esseff, P. J. (1980). Developing instructional materials. Columbia: ESF Press.

Hutchinson, T., \& Waters, A. (1991). English for specific purposes: A learningcenter approach. Cambridge: Cambridge University Press.

Kitao, Kenji, \& Kitao. (1997). Selecting and developing teaching/learning materials the internet. TESL Journal, 4(4). Retrieved, from http://teslj.org/Articles/KitaoMaterials.html

Tomlinson, B. (2001). Materials development. In Carter, C. \& Nunan, D. (Eds). The Cambridge guide to teaching English to speakers of other languages (Pp. 66). Cambridge; Cambridge University Press.

(1995). Choosing your coursebook. Oxford: Macmillan Heinemann. 
112 | Journal on English as a Foreign Language, Volume 5, Number 2, September 2015 